\title{
Soil Organic Carbon Fractions and Aggregation in the Southern Piedmont and Coastal Plain
}

\author{
Hector J. Causarano* \\ USDA-ARS Hydrology and Remote Sensing Lab. \\ Bldg. 007, Rm. 126 \\ BARC-West \\ 10300 Baltimore Blvd. \\ Beltsville, MD 20705
}

\section{Alan J. Franzluebbers \\ USDA-ARS Natural Resource Conservation Center Watkinsville, GA 30677}

Joey N. Shaw

Dep. of Agronomy and Soils

Auburn Univ.

Auburn, AL 36849

\section{Wayne Reeves}

USDA-ARS Natural Resource Conservation Center Watkinsville, GA 30677

\section{Randy L. Raper \\ USDA-ARS National Soil Dynamics Lab. \\ Auburn, AL 36832}

\section{Wesley Wood}

Dep. of Agronomy and Soils

Auburn Univ.

Auburn, AL 36849
Quantification of the impact of long-term agricultural land use on soil organic C (SOC) is important to farmers and policymakers, but few studies have characterized land use and management effects on SOC across physiographic regions. We measured the distribution and total stock of SOC to a depth of $20 \mathrm{~cm}$ under conventional tillage (CvT), conservation tillage (CsT), and pasture in 87 production fields from the Southern Piedmont and Coastal Plain Major Land Resource Areas. Across locations, SOC at a depth of 0 to $20 \mathrm{~cm}$ was: pasture $(38.9$ $\left.\mathrm{Mg} \mathrm{ha}^{-1}\right)>\operatorname{CsT}\left(27.9 \mathrm{Mg} \mathrm{ha}^{-1}\right)>\operatorname{CvT}\left(22.2 \mathrm{Mg} \mathrm{ha}^{-1}\right)(\mathrm{P} \leq 0.02)$. Variation in SOC was explained by management $(41.6 \%)$, surface horizon clay content $(5.2 \%)$, and mean annual temperature (1.0\%). Higher clay content and cooler temperature contributed to higher SOC. Management affected SOC primarily at the soil surface $(0-5 \mathrm{~cm})$. All SOC fractions (i.e., total SOC, particulate organic $\mathrm{C}$, soil microbial biomass $\mathrm{C}$, and potential $\mathrm{C}$ mineralization) were strongly correlated across a diversity of soils and management systems $(\boldsymbol{r}=0.85-0.96)$. The stratification ratio (concentration at the soil surface/concentration at a lower depth) of SOC fractions differed among management systems $(P \leq 0.0001)$, and was 4.2 to 6.1 under pastures, 2.6 to 4.7 under CsT, and 1.4 to 2.4 under CvT; these results agree with a threshold value of 2 to distinguish historically degraded soils with improved soil conditions from degraded soils. This on-farm survey of SOC complements experimental data and shows that pastures and conservation tillage will lead to significant SOC sequestration throughout the region, resulting in improved soil quality and potential to mitigate $\mathrm{CO}_{2}$ emissions.

Abbreviations: CMIN, potential C mineralization; CsT, conservation tillage row cropping; CvT, conventional tillage row cropping; MLRA, Major Land Resource Area; MWD, mean-weight diameter; POC, particulate organic carbon; SMBC, soil microbial biomass carbon; SOC, soil organic C; SOM, soil organic matter.
A great research effort has been invested in estimating soil organic carbon (SOC) sequestration in croplands of the United States (Lal et al., 1998). Despite this effort, it is difficult to make comparisons among management systems or across regions because some reports lack bulk density information, unequal soil depths have been sampled, or different analytical procedures have been used. Furthermore, most experiments have been conducted on relatively flat terrain where $\mathrm{C}$ loss by erosion has been low. A known limitation for comparing $\mathrm{C}$ stocks among agricultural systems is the dearth of information from pasture lands, which occupy significant arable land

Soil Sci. Soc. Am. J. 72:221-230

doi:10.2136/sssaj2006.0274

Received 8 Aug. 2006.

*Corresponding author (Hector.Causarano@ars.usda.gov).

(c) Soil Science Society of America

677 S. Segoe Rd. Madison WI 53711 USA

All rights reserved. No part of this periodical may be reproduced or transmitted in any form or by any means, electronic or mechanical, including photocopying, recording, or any information storage and retrieval system, without permission in writing from the publisher. Permission for printing and for reprinting the material contained herein has been obtained by the publisher.
(National Agricultural Statistics Service, 2002). Therefore, more research is needed to better characterize potential SOC sequestration, especially with regard to the diversity of soil types and management in the Southern Piedmont and Coastal Plain Major Land Resource Areas (MLRAs).

The long history of exhaustive tillage and subsequent soil erosion has depleted SOC in the southeastern United States. Soil tillage buries residues, disrupts macroaggregates, increases aeration, and stimulates microbial breakdown of SOC (Reeves, 1997). With sound soil and crop management, the warm and humid climate with a long growing season characteristic of this region allows high cropping intensity and biomass production, which translates into a high potential for photosynthetic C fixation and SOC sequestration (Reeves and Delaney, 2002). Increasing SOC content is appealing because it has a critical role in improving soil quality and has significant potential to cost-effectively attenuate the detrimental effects of rising atmospheric $\mathrm{CO}_{2}$ and other greenhouse gases.

Franzluebbers (2005) compiled published data on SOC comparing conventional tillage vs. no-till (NT) systems in the southeastern United States. From 96 comparisons at 22 locations in the southeastern United States, SOC was $25.2 \pm 11.6 \mathrm{Mg} \mathrm{ha}^{-1}$ under conventional tillage (CvT) and $28.5 \pm 11.3 \mathrm{Mg} \mathrm{ha}^{-1}$ under 
NT, in which the sampling depth was $19 \pm 5 \mathrm{~cm}$. The increased rate of SOC sequestration in NT compared with CvT was 0.42 $\pm 0.46 \mathrm{Mg} \mathrm{C} \mathrm{ha}^{-1} \mathrm{yr}^{-1}$. Recent SOC sequestration rate estimates from NT compared with CvT management systems in other regions of the United States include: $0.48 \pm 0.59 \mathrm{Mg} \mathrm{C} \mathrm{ha}^{-1} \mathrm{yr}^{-1}$ in the central United States (Johnson et al., 2005), $0.30 \pm 0.21$ $\mathrm{Mg} \mathrm{C} \mathrm{ha}{ }^{-1} \mathrm{yr}^{-1}$ in the southwestern United States (Martens et al., 2005), and $0.27 \pm 0.19 \mathrm{MgC} \mathrm{ha}^{-1} \mathrm{yr}^{-1}$ in the northwestern United States and western Canada (Liebig et al., 2005). Lal et al. (1998) estimated a value of $0.5 \mathrm{Mg} \mathrm{C} \mathrm{ha}^{-1} \mathrm{yr}^{-1}$ for the entire United States. From an earlier literature review on SOC storage in croplands that included 111 comparisons across the United States and Canada, Franzluebbers and Steiner (2002) outlined a geographical area in North America having the highest SOC sequestration potential with adoption of NT that included the central and upper southeastern United States. Clearly, adoption of conservation tillage (CsT) in the Piedmont and Coastal Plain regions has a high potential for SOC sequestration.

Under similar macroclimatic and management history, the less disturbed the soil, the greater the SOC content. Increasing SOC content with less disturbance can be attributed to slower decomposition in the surface residue layer as a result of less favorable microclimatic conditions for microbial activity. Climatic conditions are expected to influence soil organic matter (SOM) contents. Jenny (1941) observed that total soil $\mathrm{N}$ increased with increasing precipitation and declining temperature. Therefore, each macroclimatic region will have a characteristic range of SOM content. How management interacts with climatic conditions in affecting SOC changes is of interest.

Soil organic matter contains 50 to $58 \% \mathrm{C}$ (Nelson and Sommers, 1982) and is a complex mixture of organic compounds with different turnover times (Christensen, 2001). Different pools of SOM have been conceptualized for modeling SOC dynamics (Skjemstad et al., 1998). Since the turnover of SOM is a biological process that depends not only on the chemical composition of the substrate but also on the nature of its association with mineral particles (soil structure), methods have been developed to isolate fractions according to the size and density of individual soil particles or aggregates (Christensen, 2001). The particulate organic matter (Cambardella and Elliott, 1992 ) is an uncomplexed fraction of SOM composed of particulate $(>0.05 \mathrm{~mm})$, partially decomposed plant and animal residues, fungal hyphae, spores, root fragments, and seeds. This fraction provides a substrate for microbial activity and is an important agent in the formation of macroaggregates. It is a fraction that lies intermediate between litter (fast turnover) and mineral-associated SOM (slow turnover). Soil microbial biomass $\mathrm{C}(\mathrm{SMBC})$ and potentially mineralized $\mathrm{C}(\mathrm{CMIN})$ are considered active fractions of SOM. These active fractions are important for supplying plant nutrients, decomposing organic residues, and developing soil structure (Franzluebbers et al., 2000a). Particulate organic matter, SMBC, CMIN, soil aggregation, and the stratification ratio (i.e., a soil property at the soil surface divided by the same soil property at a lower depth) are important indicators of dynamic soil quality because they are responsive to changes in soil management (e.g., pastures to croplands or CsT to CvT agriculture) (Franzluebbers, 2002; Wander, 2004).
Well-developed and highly weathered Ultisols, with clayey or loamy subsoils and kaolinitic or siliceous mineralogy, are predominant in the uplands of the Southern Piedmont and Coastal Plain (NRCS, 2006). Surface horizon texture typically varies from loamy sand to sandy loam in the Coastal Plain, and from sandy loam to clay in the Piedmont. Soil texture, particularly clay content, influences the stabilization of SOM. Mechanisms for SOM stabilization include surface complexation with clay minerals and physical protection in micropores formed by clay aggregates (Christensen, 1996).

We hypothesized that practical assessment of SOC sequestration in pasture and crop lands would be obtained by measuring SOC stocks on farmers' fields. Our objectives were to: (i) quantify the differences in SOC stocks and aggregation among three primary management systems; (ii) isolate SOC fractions with depth; and (iii) determine the effect of climate and surface horizon clay content on SOC stocks.

\section{MATERIALS AND METHODS Site Characteristics and Sampling Procedures}

The Southern Piedmont and Coastal Plain MLRAs extend along most of the southeastern United States (NRCS, 2006). Mean annual temperature ranges from $14^{\circ} \mathrm{C}$ in the north to $20^{\circ} \mathrm{C}$ in the south. Mean annual precipitation typically exceeds $1000 \mathrm{~mm}$, but is $>1400$ $\mathrm{mm}$ along the coastlines and in the western portion. Dominant upland soils of both MLRAs are Ultisols (e.g., Kanhapludults, Kandiudults, Hapludults, Paleudults) with loamy- to clayey-textured argillic or kandic horizons, mesic to thermic temperature regimes, a udic moisture regime, and kaolinitic or mixed mineralogy. Most upland Piedmont soils have developed on rolling landscapes (peneplains), are well drained and moderately permeable, and reside at 100 to $400 \mathrm{~m}$ above mean sea level. Although most of the land was once cultivated, much of it has been converted to pine (Pinus spp.), hardwoods, and pasture. Cash crops include soybean [Glycine max (L) Merr.], corn (Zea mays L.), cotton (Gossypium hirsutum L.), wheat (Triticum aestivum L.), and to a lesser extent tobacco (Nicotiana tabacum L.). In contrast, Coastal Plain soils were formed from unconsolidated fluvio-marine sediments, and are located at 25 to $200 \mathrm{~m}$ above mean sea level. Much arable land is dedicated to cash crops such as cotton, peanut (Arachis hypogaea L.), corn, and soybean. Timber production and livestock farming are important in the Coastal Plain, and pastures are used mostly for beef cattle (Bos taurus).

A total of 29 locations on farms in the Piedmont and Coastal Plain MLRAs of Alabama, Georgia, South Carolina, North Carolina, and Virginia were sampled between May 2004 and May 2005. Three sites (3-5 ha each) differing in land use and tillage management were sampled from the same soil map unit (Order 2 NRCS soil surveys) at a particular location. Because soils were sampled within the same map unit, it was assumed that drainage class, slope, and other associated properties were similar across the three sites at each location. We recognize, however, that at the scale of Order 2 mapping, inclusions occur within map units. Three management systems were investigated:

1. CvT cropland, defined as a system with inversion tillage that buries crop residues. Common practices included moldboard or chisel plowing (primary tillage) and disking before seedbed preparation (secondary tillage).

2. CsT cropland, consisting of minimum soil inversion with $>30 \%$ residue cover on the surface. Farms that incorporated cover crops (e.g., oat [Avena sativa 
L.] or rye [Secale cereale L.]) in the rotation were preferentially sampled; this resulted in 18 out of the 29 sampled sites having cover crops in the rotation. No-till and strip-tillage (noninversion in-row subsoiling to disturb a zone $40 \mathrm{~cm}$ deep and 20-40 cm wide at the surface) practices were common.

3. Pastures consisted of perennial grass species that were grazed or hayed. Sites were long established under a particular management; i.e., 5 to $40 \mathrm{yr}$ under CvT, 5 to $30 \mathrm{yr}$ under CsT, and 10 to $60 \mathrm{yr}$ under pasture. There was a broad range of crops and related management operations.

With our analytical survey approach, we were not able to determine the specific effects on soil responses of several key management components, such as cover crops, fertilization, weed and pest control, etc. In spite of this, the approach allowed us to compare management systems (pasture, CsT, and CvT) as a whole for their effects on SOC fractions and aggregation. Also, we could not quantify the effect of duration of a particular management system. Changes in SOC were assumed larger during the first few years after a change in tillage management. Given that only five out of the 29 sampling locations had management systems with $<10-\mathrm{yr}$ duration, we assumed the difference in duration of the management practices had minimal effect on SOC

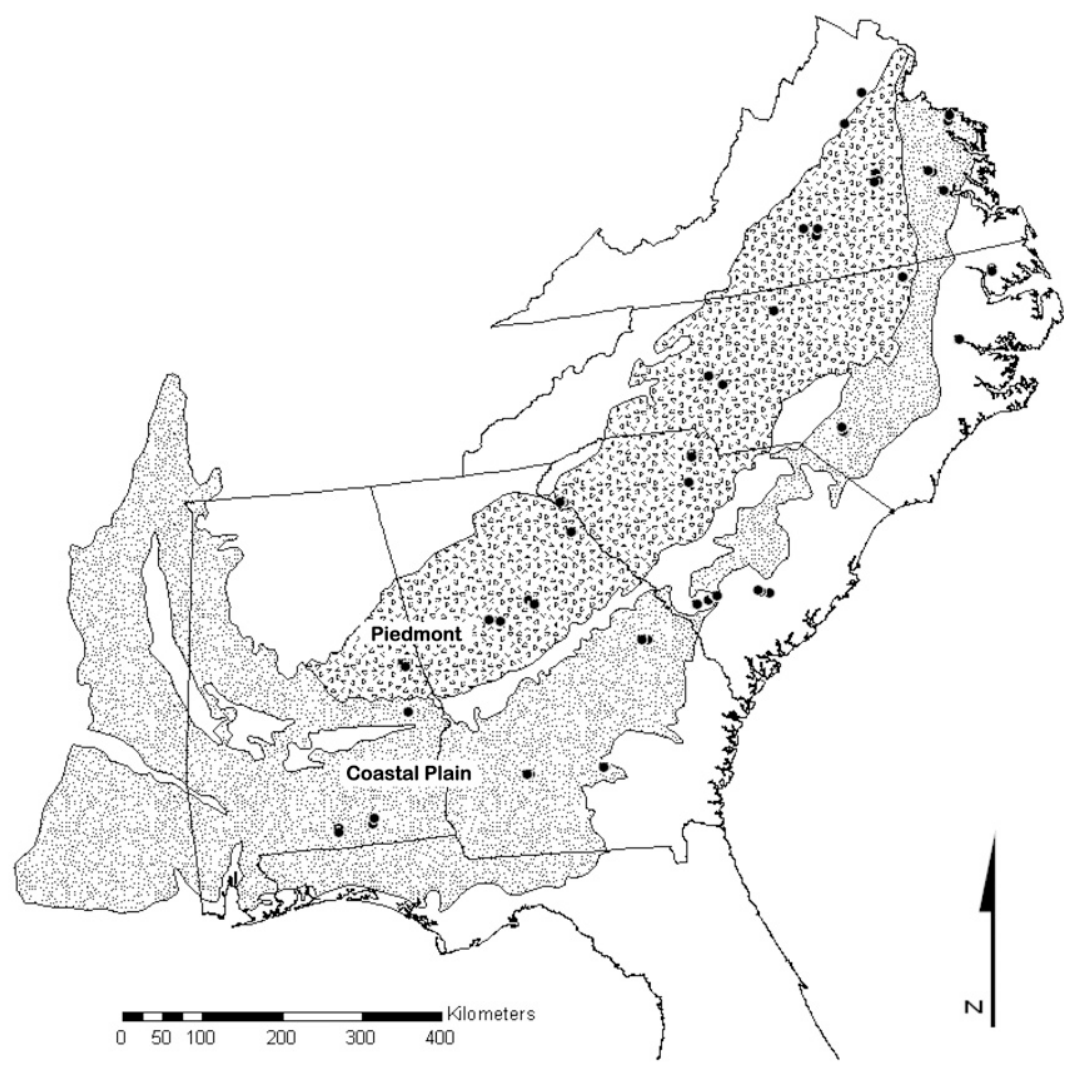

Fig. 1. Location of Piedmont and Coastal Plain Major Land Resource Areas and sampling sites. changes. The 29 locations were relatively evenly distributed throughout the study area (Fig. 1).

Soil samples were taken after planting, from May to August. Before sampling, sites were evaluated to determine representative areas; obvious areas of atypical variability were avoided. At each site, eight randomized soil core samples (5-cm diameter, 20-cm depth) were composited. On croplands, four soil cores were taken within rows and four between rows. At the time of sampling, information was collected on crop management history and positions were georeferenced with a geographic positioning system. Climate data (precipitation and temperature) were obtained by matching the site's coordinates with data (30-yr normals) from the Spatial Climate Analysis Service (2005).

\section{Sample Preparation and Laboratory Analyses}

Soil cores were cut at 0 to 5,5 to 12.5 , and 12.5 to $20 \mathrm{~cm}$ and air dried. Oven-dry bulk density was determined for each depth by calculating mass per unit volume (Blake and Hartge, 1986). Air-dry samples were then gently crushed and passed through a $4.75-\mathrm{mm}$ screen. Stones $(>4.75 \mathrm{~mm})$ were removed from the soil samples. A subsample was oven dried $\left(105^{\circ} \mathrm{C}, 24 \mathrm{~h}\right)$ to obtain a correction factor and express analytical results on an oven-dried basis. All analytical procedures, except $\mathrm{C}$ determination, were performed on $<4.75$-mm soil samples.

Particulate organic C, SMBC, and CMIN were determined following the procedure of Franzluebbers et al. (2000a). Briefly, duplicate subsamples ( 35 and $65 \mathrm{~g}$ for $0-5$ - and 5-20-cm depths, respectively) were moistened to $50 \%$ water-filled pore space and incubated at $25 \pm$ $1^{\circ} \mathrm{C}$ in 1 - $\mathrm{L}$ canning jars containing vials with $10 \mathrm{~mL}$ of $1.0 \mathrm{~mol} \mathrm{~L}^{-1}$ $\mathrm{NaOH}$ to absorb $\mathrm{CO}_{2}$, and small vials containing water to maintain humidity. Alkali traps were replaced at 3 and $10 \mathrm{~d}$, and removed at 24 $\mathrm{d}$ for $\mathrm{C}$ mineralization determination. Evolved $\mathrm{CO}_{2}$ was determined by titration of alkali with $1.0 \mathrm{~mol} \mathrm{~L}^{-1} \mathrm{HCl}$. At $10 \mathrm{~d}$, a subsample was removed, fumigated with chloroform, and incubated separately for another $10 \mathrm{~d}$ under the same conditions to determine the flush of $\mathrm{CO}_{2}$ representing microbial biomass $\mathrm{C}$ according to the equation (Voroney and Paul, 1984)

$$
\mathrm{SMBC}=\left(\mathrm{mg} \mathrm{CO} \mathrm{CO} \mathrm{kg}^{-1} \text { soil }\right)_{\text {fumigated }} / k_{\mathrm{c}}
$$

where $k_{\mathrm{c}}=0.41$. The particulate organic fraction was determined from the fumigated subsamples at the end of the 10-d incubation period. Subsamples were shaken in $100 \mathrm{~mL}$ of $0.1 \mathrm{~mol} \mathrm{~L}^{-1} \mathrm{Na}_{4} \mathrm{P}_{2} \mathrm{O}_{7}$ for $16 \mathrm{~h}$; the suspension was diluted to $1 \mathrm{~L}$ with distilled water and allowed to settle for $5 \mathrm{~h}$. Clay content was determined with a hydrometer. The soil suspension was then passed through a $0.053-\mathrm{mm}$ screen and the retained sand-sized material transferred to a drying bottle and weighed after oven drying at $55^{\circ} \mathrm{C}$ for $72 \mathrm{~h}$. Soil C determined on this fraction was considered POC.

For soil C, 25-g subsamples were finely ground $(<250 \mu \mathrm{m})$ on an apparatus similar to Kelley (1994). Determinations followed the dry combustion method of Nelson and Sommers (1982) using a LECO carbon analyzer (LECO Corp., St. Joseph, MI). Each batch contained 49 samples; precision and accuracy were calculated by duplicate analysis on $10 \%$ of the samples and by introducing a LECO reference standard and a check soil in each batch. Calculated errors were $<5 \%$, therefore it was not necessary to repeat analysis on any batch. All soils were acid without carbonates, therefore it was assumed that total $\mathrm{C}$ was equivalent to organic $\mathrm{C}$.

Dry-stable and water-stable aggregate distributions were determined on the 0 - to $5-\mathrm{cm}$ samples following a procedure similar to Franzluebbers et al. (2000b). Dry stability was determined by placing 
a 100-g soil sample on the uppermost of a set of sieves (20-cm diameter), shaking for $1 \mathrm{~min}$ on a vibrating CSC Scientific Sieve Shaker (Catalogue no. 18480, CSC Scientific, Fairfax, VA), and weighing the soil retained on the 1.0-, 0.25, and $0.053-\mathrm{mm}$ screens and that passing the 0.053 -mm screen.

Water-stable aggregate distribution was determined by placing the same soil sample used for dry-stable aggregate distribution on the uppermost of two sieves (17.5-cm diameter with openings of 1.0 and $0.25 \mathrm{~mm}$ ), immersing directly in water, and oscillating for $10 \mathrm{~min}$ (20$\mathrm{mm}$ stroke length, 31 cycles $\left.\mathrm{min}^{-1}\right)$. After the 10 -min period, the two sieves were removed and oven dried $\left(55^{\circ} \mathrm{C}, 24 \mathrm{~h}\right)$. Water containing soil passing the $0.25-\mathrm{mm}$ screen was poured over a $0.053-\mathrm{mm}$ screen and the soil rinsed with a gentle stream of water. The soil retained was then transferred into a drying tray with a small stream of water. The $<0.053$-mm fraction was calculated as the difference between the initial soil weight and the summation of the other fractions. All fractions were oven dried at $55^{\circ} \mathrm{C}$ to constant mass. Mean-weight diameter of both dry- and water-stable aggregates was calculated by summing the products of the aggregate fraction weight and the mean diameter of the aggregate classes.

\section{Calculation of Soil Organic Carbon Stocks}

Concentrations of SOC were converted to mass per unit area for a fixed depth $(0-20 \mathrm{~cm})$ by calculating the product of concentration, bulk density, and thickness. To account for variation in soil mass between samples, "equivalent soil depths" were calculated following the method described by Ellert and Bettany (1995). Additional thickness of the subsurface layer required for attaining equivalent soil mass was computed as follows:

$$
T_{\text {add }}=\frac{\left(M_{\text {soil,equiv }}-M_{\text {soil,surf }}\right) 0.0001 \text { ha m}^{-2}}{\rho_{\mathrm{b}}}
$$

where $T_{\text {add }}$ is the additional thickness of the layer being adjusted to attain the equivalent soil mass (m), $M_{\text {soil, equiv }}$ is the mass of the heaviest layer

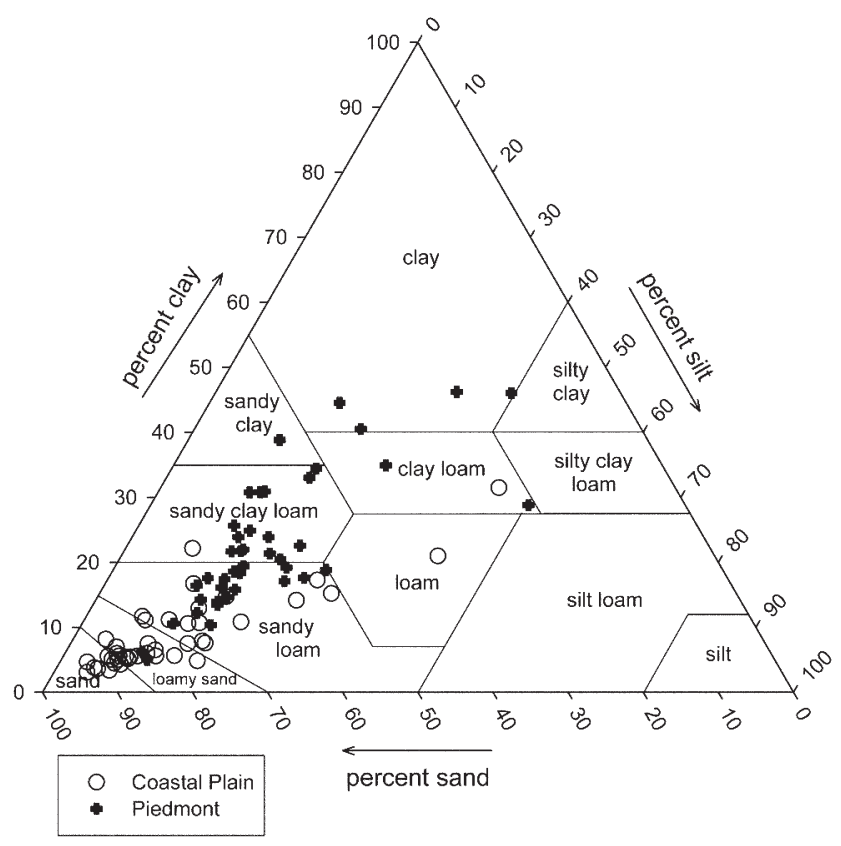

Fig. 2. Surface $(0-20 \mathrm{~cm})$ texture of soils sampled in the Piedmont and Coastal Plain Major Land Resource Areas.
$\left(\mathrm{Mg} \mathrm{ha}^{-1}\right), M_{\text {soil, surf }}$ is the mass of the layer being adjusted $\left(\mathrm{Mg} \mathrm{ha}^{-1}\right)$, and $\rho_{\mathrm{b}}$ is the bulk density of the layer being adjusted $\left(\mathrm{Mg} \mathrm{m}^{-3}\right)$.

\section{Calculation of Stratification Ratio}

Franzluebbers (2002) defined the stratification ratio as a soil property at the soil surface divided by the same soil property at a lower depth, such as the bottom of the tillage layer. Stratification ratios were calculated from soil properties at the 0 - to $5-\mathrm{cm}$ depth divided by those at 12.5- to 20-cm depth.

\section{Statistical Analysis}

Soil properties were analyzed for variance (one-way ANOVA) using PROC GLM in SAS (SAS Institute, 2003) with MLRA, locations nested within MLRA, and management as independent variables, and soil properties as dependent variables. When indicated, an analysis of covariance (ANCOVA) with clay as the covariable was performed to account for the effect of clay content on SOC. The effect of mean annual temperature and precipitation on $\mathrm{C}$ was analyzed using PROC RSREG to test for the significance $(P=0.05)$ of climate variables and to examine the structure of the estimated response surface.

\section{RESULTS AND DISCUSSION Total Soil Organic Carbon Stock}

Pasture and CvT soils tended to have lower bulk density than CsT soils $(0-20 \mathrm{~cm})$, such that an additional layer $(1.0 \pm$ $1.3 \mathrm{~cm}$ ) was required to attain equivalent soil mass. Soil organic $\mathrm{C}$ calculated on an equal-mass basis (i.e., adjusted using Eq. [2]), however, did not change the comparative values in relation to SOC on an equal-volume basis. Variation in SOC was explained by management (41.6\%), clay content $(5.2 \%)$, and mean annual temperature (1.0\%).

Total organic $\mathrm{C}$ in the 0 - to 20 -cm layer was affected by MLRA (32.2 and $27.0 \mathrm{Mg} \mathrm{ha}^{-1}$ in the Piedmont and Coastal Plain, respectively; $P \leq 0.002)$ and by management $(38.9,27.9$, and $22.2 \mathrm{Mg} \mathrm{ha}^{-1}$ under pasture, CsT, and CvT, respectively; $P \leq 0.001)$. The interaction between MLRA and management was not significant. These SOC values agreed with published data. Across several studies, $S O C$ to an average depth of $18 \mathrm{~cm}$ in the Piedmont and Coastal Plain regions was $24.4 \mathrm{Mg} \mathrm{ha}^{-1}$ under CsT and 21.1 $\mathrm{Mg} \mathrm{ha}^{-1}$ under CvT (Franzluebbers, 2005). Data for SOC under pasture are rare, but our results were similar to the 37.8 and $35.3 \mathrm{Mg} \mathrm{ha}^{-1}$ reported by Franzluebbers et al. (2000a) and Fesha et al. (2002) for long-term pastures (20$\mathrm{cm}$ depth) in the Piedmont of Georgia and the Coastal Plain of Alabama, respectively. Thus, the use of conservation tillage and pastures is an effective strategy for restoring $\mathrm{C}$ stocks in agricultural systems in these MLRAs. Restoration of higher levels of SOC is crucial for improvement of soil structure, soil fertility, and crop production, and would improve sustainability of agricultural production.

The surface $(0-20 \mathrm{~cm})$ texture of Coastal Plain soils was mostly sand, loamy sand, or sandy loam, while the texture of Piedmont soils was primarily sandy loam, sandy clay loam, or clay (Fig. 2). When clay content was included as a covariate, the difference in SOC between MLRAs was not significant $(P$ $=0.9$ ), while differences in SOC among management systems remained significant $(P \leq 0.0001)$. Clay content explained $35 \%$ of SOC variability in CsT systems and 33\% in CvT systems (Fig. 3). All sampled soils except one were upland, well- 


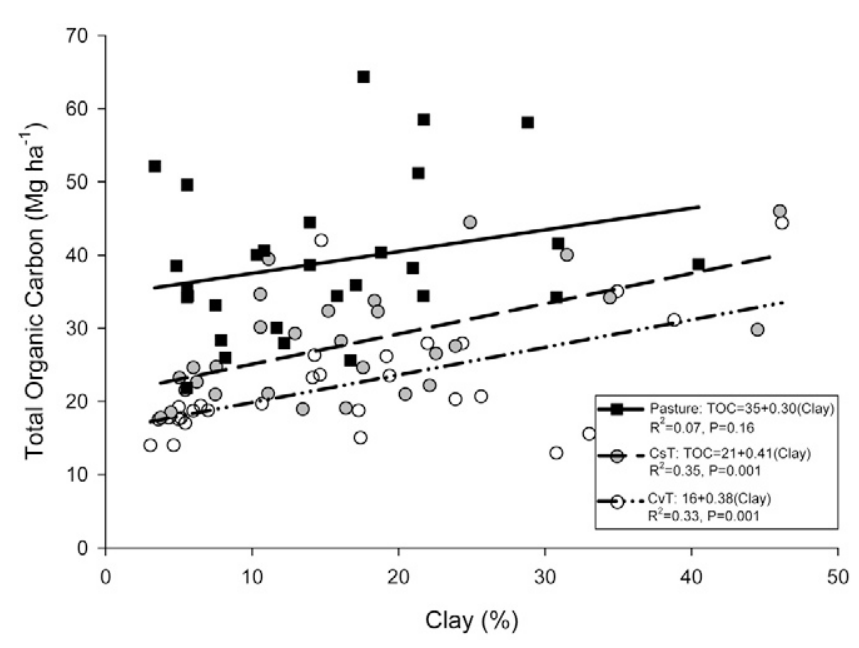

Fig. 3. Effect of surface horizon clay content on total soil organic C (TOC, 0-20 cm) under long-term management as pasture, conservation tillage (CsT), and conventional tillage (CvT) systems from 87 sites in the Piedmont and Coastal Plain Major Land Resource Areas.

drained Ultisols. The exception was an upland Alfisol (Ultic Hapludalf) in the Coastal Plain of Virginia. Ultisols are highly weathered, with clay mineralogy dominated by low-activity minerals including kaolinite, hydroxyinterlayered vermiculite, gibbsite, and $\mathrm{Fe}$ oxides. Greater clay concentration could improve water and nutrient retention, and therefore allow greater input of $\mathrm{C}$, resulting in overall greater SOC. The mechanism by which clay particles stabilize SOC has not been well elucidated. Some research has indicated that mineralogy influences the mechanisms of $\mathrm{C}$ stabilization. For example, in soils with highly weathered mineralogy, the interaction between positive charges associated with oxides and negative charges of clay minerals forms strong aggregates that can physically protect organic matter (van Veen et al., 1984). In soils with mixed mineralogy, organic matter may act as the primary binding agent for soil aggregates, where the negative surface charges of SOM and clay minerals are mutually bound to positively charged polyvalent metal cations (Edwards and Bremner, 1967). In contrast, Wattel-Koekkoek et al. (2001) concluded that the total amount of organic $\mathrm{C}$ in the clay-size fraction was independent of clay mineralogy.

By first accounting for clay content as a covariate $(P<0.0001)$, temperature $(P=0.02)$ had only a minor influence on SOC, explaining $1.0 \%$ of its variation. Precipitation did not have a significant effect on SOC variation. The range of climatic conditions in this study was small compared with studies of larger
Table 1. Pearson correlation coefficients among carbon fractions. Samples correspond to 87 sites spanning the Piedmont and Coastal Plain Major Land Resource Areas.

\begin{tabular}{lcccc} 
& SOC & POC & SMBC & CMIN \\
\hline Total organic C (SOC) & - & $* * *$ & $* * *$ & $* * *$ \\
Particulate organic C (POC) & 0.87 & - & $* * *$ & $* * *$ \\
Soil microbial biomass C (SMBC) & 0.95 & 0.85 & - & $* * *$ \\
C mineralized in 24 d (CMIN) & 0.94 & 0.85 & 0.96 & - \\
\hline
\end{tabular}

*** Significant at $P \leq 0.001$.

geographic regions (Jenny, 1941; Franzluebbers and Steiner, 2002), which probably limited its influence on SOC.

\section{Soil Organic Carbon Fractions}

Pastures contained significantly greater SOC than cropland at $0-$ to $5-\mathrm{cm}$ depth (1.9 times greater than CsT and 3.1 times greater than $\mathrm{CvT}$ ), but there were no differences among management systems at lower depths $(5-20 \mathrm{~cm})$. A similar management effect was observed for POC, SMBC, and CMIN (Fig. 4). Pastures and CsT had less soil disturbance, which allowed SOC fractions to accumulate at the surface. Aboveground residues decompose more slowly than incorporated residues because reduced contact with the soil increases drying and rewetting and reduces interactions with soil fauna (a) Total Organic $\mathrm{C}\left(\mathrm{g} \mathrm{kg}^{-1}\right)$

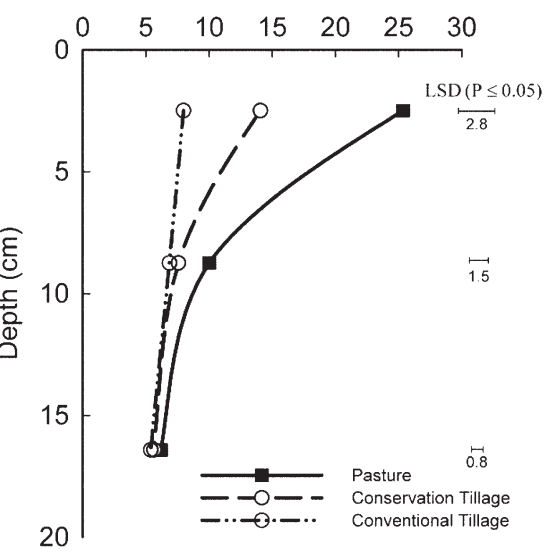

(c) Soil Microbial Biomass $\mathrm{C}\left(\mathrm{g} \mathrm{kg}^{-1}\right)$

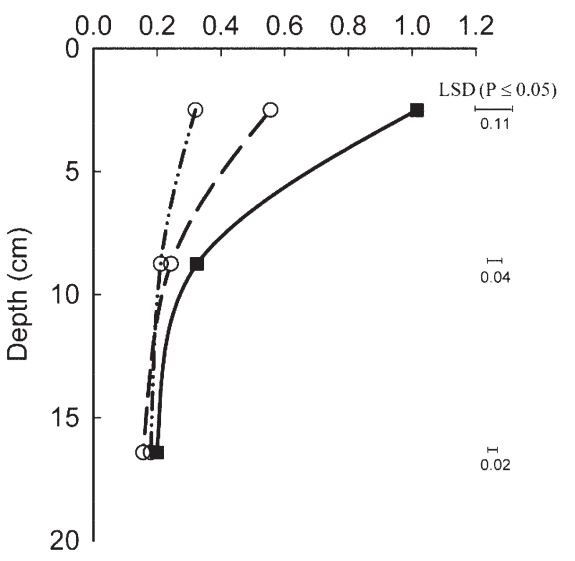

(b) Particulate Organic $\mathrm{C}\left(\mathrm{g} \mathrm{kg}^{-1}\right)$
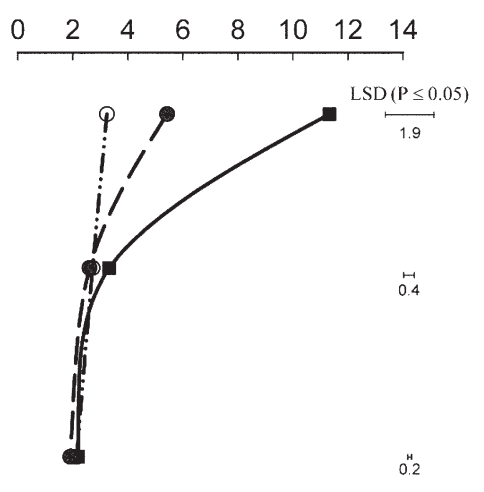

Fig. 4. Depth distribution of (a) total soil organic C, (b) particulate organic C, (c) soil microbial biomass $C$, and (d) $C$ mineralized in $24 \mathrm{~d}$. Samples correspond to 87 sites in the Piedmont and Coastal Plain Major Land Resource Areas. 


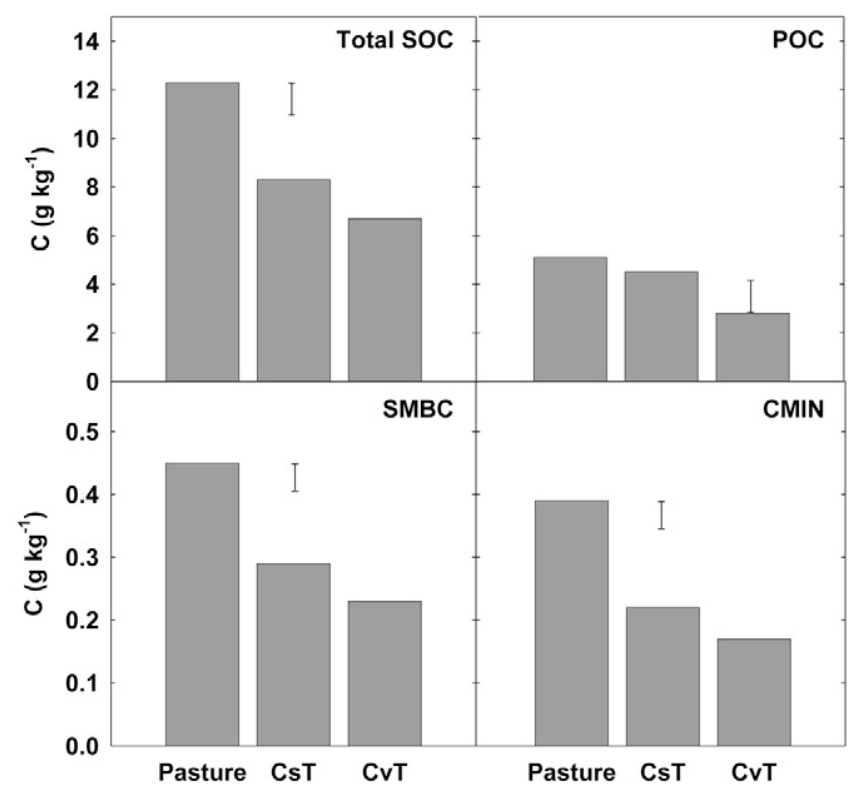

Fig. 5. Effect of pasture, conservation tillage (CsT), and conventional tillage (CvT) on total soil organic $\mathrm{C}$ (SOC), particulate organic C (POC), soil microbial biomass C (SMBC), and $\mathrm{C}$ mineralized in $24 \mathrm{~d}(\mathrm{CMIN})$ at 0 - to $20-\mathrm{cm}$ depth. Error bars are LSD $(P \leq 0.05)$.

and microbes. The average concentrations of total SOC, POC, SMBC, and CMIN within the surface $20 \mathrm{~cm}$ followed the order: pasture $>\mathrm{CsT}>\mathrm{CvT}(P \leq 0.05)$ (Fig. 5). Franzluebbers and Stuedemann (2002) found similar results comparing longterm pastures with long-term CsT in the Piedmont of Georgia. Greater total SOC, POC, SMBC, and CMIN under pastures compared with croplands could be due to a variety of factors, including a greater overall rate of photosynthetic activity resulting in greater $\mathrm{C}$ inputs throughout the year (because of the growth capabilities of perennial vs. annual plant species), and less $\mathrm{C}$ exported via cattle production compared with crop harvest. The POC/total SOC ratio decreased with soil depth in pasture and CsT, but remained fairly constant in CvT. This suggests that POC was a larger portion of total SOC at the soil surface, probably as a result of the accumulation of plant and animal residues, root fragments, and other labile organic materials where soil remained undisturbed by tillage operations. There were no statistical differences in POC/total SOC among management systems (data not shown).

Across management systems, sampling depths, and physiographies, there was a strong relationship among all SOC fractions (Table 1). The relationship between POC and total SOC $\left(\mathrm{POC}=-0.03+0.42\right.$ total SOC; $\left.R^{2}=0.75, n=261\right)$ suggests that $\mathrm{C}$ accumulation in this warm and humid region was largely due to increases in the POC fraction; i.e., for every unit of total SOC accumulated, $42 \%$ consisted of POC. Franzluebbers and Stuedemann (2002) reported 57\% POC for every unit of total SOC under long-term pastures in the southern Piedmont.

Potential C mineralization during $24 \mathrm{~d}(\mathrm{CMIN})$ decreased with depth (Fig. 4d) and was different among management systems in the order: pasture $>\operatorname{CsT}>\operatorname{CvT}(P \leq 0.05$; Fig. 5). The response in CMIN was similar to that observed for SMBC and was strongly related to all SOC fractions (Table 1). At the 0 - to 5 -cm depth, $\mathrm{C}$ mineralization under pasture was twice that under CsT and almost four times that under CvT. Greater CMIN under pasture and CsT suggests that less disturbed systems led to accumulation of potentially mineralizable $\mathrm{C}$ substrates.

In soils of the Piedmont, Franzluebbers (1999) observed an inverse relationship between CMIN and soil clay content; i.e., the clay fraction in soils protected soil organic matter from decomposition. In our study, the relationship between CMIN and clay content was not significant.

\section{Aggregation}

Dry-stable mean-weight diameter (MWD) and aggregate-size distribution (ASD) at a depth of 0 to $5 \mathrm{~cm}$ was not different among management systems. There was a significant impact $(P<0.001)$ of management on water-stable MWD and ASD, however, following the order: pasture $>\mathrm{CsT}>\mathrm{CvT}$ (Fig. 6). Comparing dry to wet ASD, differences occurred mainly among large macroaggregates $(1000-4750 \mu \mathrm{m})$. Pasture soils withstood disruptive forces during wet sieving better than CsT soils, which were more stable than CvT soils. Large macroaggregates under pasture were $24 \%$ of the whole soil with dry and wet sieving, while large macroaggregates under CsT were $24 \%$ of the whole soil with dry sieving and $17 \%$ with wet sieving; in $\mathrm{Cv} T$, the same aggregate-size class was $22 \%$ with dry sieving and $10 \%$ with wet sieving. Disruption of macroaggregates with wet sieving increased the $<53-\mu \mathrm{m}$ aggregate-size class, i.e., silt- and clay-size microaggregates. In pasture soils, disruption occurred in the 53- to 250- $\mu \mathrm{m}$ aggregate-size class, resulting in an increase in the $<53-\mu \mathrm{m}$ aggregate-size class. Our procedure for determining dry- or water-stable MWD did not differentiate between true aggregates and large sand particles that were retained on screens, and therefore the stability of macroaggregates was more reflective of changes in soil structure induced by management.

We did not determine $\mathrm{C}$ contents of aggregate-size classes, but the fact that $\mathrm{C}$ contents were in the order: Pasture > CsT > CvT (Fig. 4), suggests that SOC was a major binding agent of large macroaggregates in these soils. Tisdall and Oades (1982) proposed a model that described microaggregates bound together into macroaggregates by microbial- and plant-derived polysaccharides, as well as roots and fungal hyphae. Reduction in macroaggregation has been associated with SOC loss with cultivation (Elliott, 1986; Gupta and Germida, 1988).

Slaking, or structural degradation in water, was most prominent in soil under CvT. Dispersed soil particles can seal pores, reduce infiltration, and increase runoff. Soil structural degradation has been associated with physical disturbance and continual exposure to wet-dry cycles that change soil microclimatic conditions and increase SOM decomposition (Paustian et al., 1997; Balesdent et al., 2000). In contrast, CsT and pasture systems not only minimize these destructive effects, but promote plant root and fungal hyphae proliferation, which are responsible for macroaggregate formation (Beare et al., 1993). Resistance of soil to structural degradation is particularly important under the climatic conditions of the Piedmont and Coastal Plain, where intense storms are common during the summer.

Clay (phyllosilicates and oxides) and organic matter are binding agents of soil aggregates (Tisdall and Oades, 1982; Kemper and Rosenau, 1984). Clay content explained $77 \%$ of the 
Mean-Weight Diameter

Dry-stable
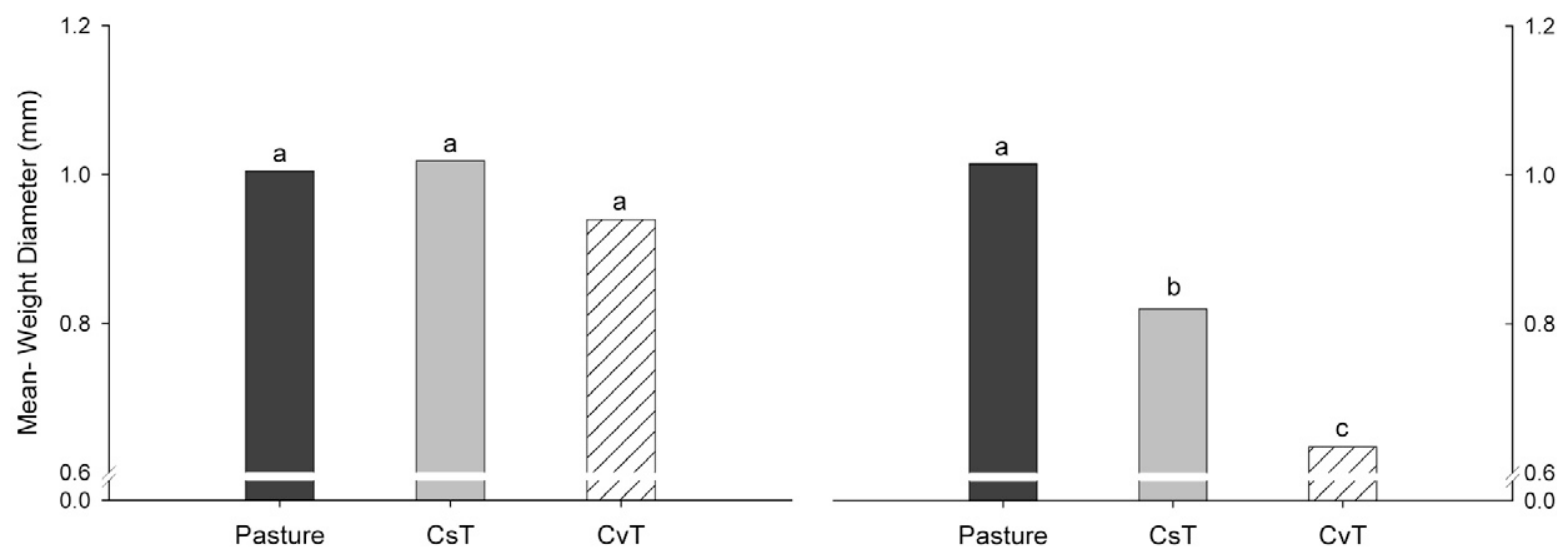

Aggregate-size distribution

Dry-stable

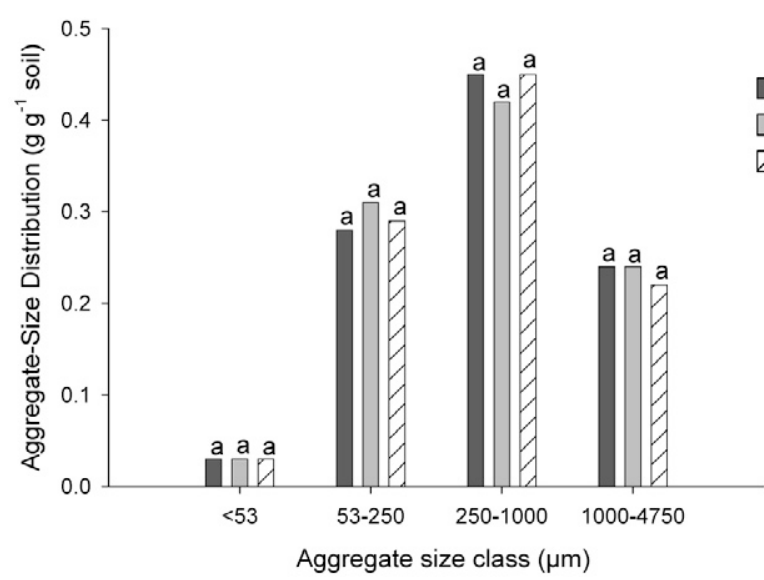

Water-stable

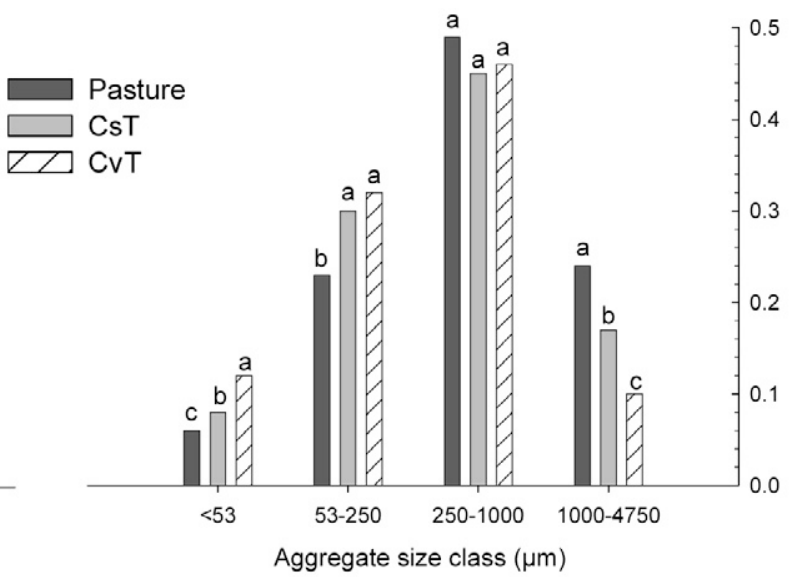

Fig. 6. Dry-stable and water-stable mean-weight diameter and aggregate-size distribution $(0-5 \mathrm{~cm})$ under pasture, conservation tillage (CsT), and conventional tillage (CvT) systems. Bars with different letters indicate significant difference in management at $P \leq 0.05$. Samples correspond to 87 sites in the Piedmont and Coastal Plain Major Land Resource Areas.

variation in the MWD of dry aggregates, but only $26 \%$ of the variation in the MWD of wet aggregates (Fig. 7). Total organic $\mathrm{C}$ explained minimal variation in the MWD of dry aggregates and $21 \%$ of the variation in the MWD of wet aggregates. These data indicated that clay-sized particles played a major role in holding dry aggregates together, but that total SOC was more important in wet aggregates. Shaw et al. (2003) found that $\mathrm{Fe}$ oxides played a more significant role in clay aggregation than SOM in Rhodic Paleudults, yet SOM has a significant role in reducing clay dispersion in these highly weathered southeastern Coastal Plain soils (Shaw et al., 2002). Management systems in the southeastern United States that maximize SOC appear to help maintain favorable soil structure.

\section{Soil Organic Carbon Stratification Ratio}

The stratification ratio of SOC fractions (e.g., total SOC, POC, SMBC, and CMIN) differed $(P \leq 0.0001)$ among management systems, and was 4.2 to 6.1 under pastures, 2.6 to 4.7 under CsT, and 1.4 to 2.4 under CvT (Fig. 8). Stratification of SOC fractions is common in natural ecosystems, and high stratification reflects relatively undisturbed soils. Franzluebbers (2002) suggested that the stratification ratio of SOC fractions could be used as a simple diagnostic tool to identify land management strategies for restoring critical soil functions, and that among soils from a diverse geographic region, the SOC stratification ratio might be a better indicator of soil quality than the total SOC content of the entire plow layer. Stratification $>2$ has been interpreted as an indicator of an undisturbed soil condition or of improving quality on previously degraded soils. Our data supported the proposed threshold stratification ratio of 2 (i.e., most ratios under $\mathrm{CvT}$ were $\leq 2$, while they were $\geq 2$ under CsT and pasture). Greater SOC stratification ratios in pastures and CsT than in CrT was a consequence of SOC accumulation at the soil surface, which should have had a positive effect on erosion control, water infiltration, and nutrient conservation. In the southeastern United States, the warm, humid climate limits SOC accumulation with depth.

The depths we used for calculation of stratification ratios $(0-5$ and $12.5-20.3)$ were similar to those used by Franzluebbers 

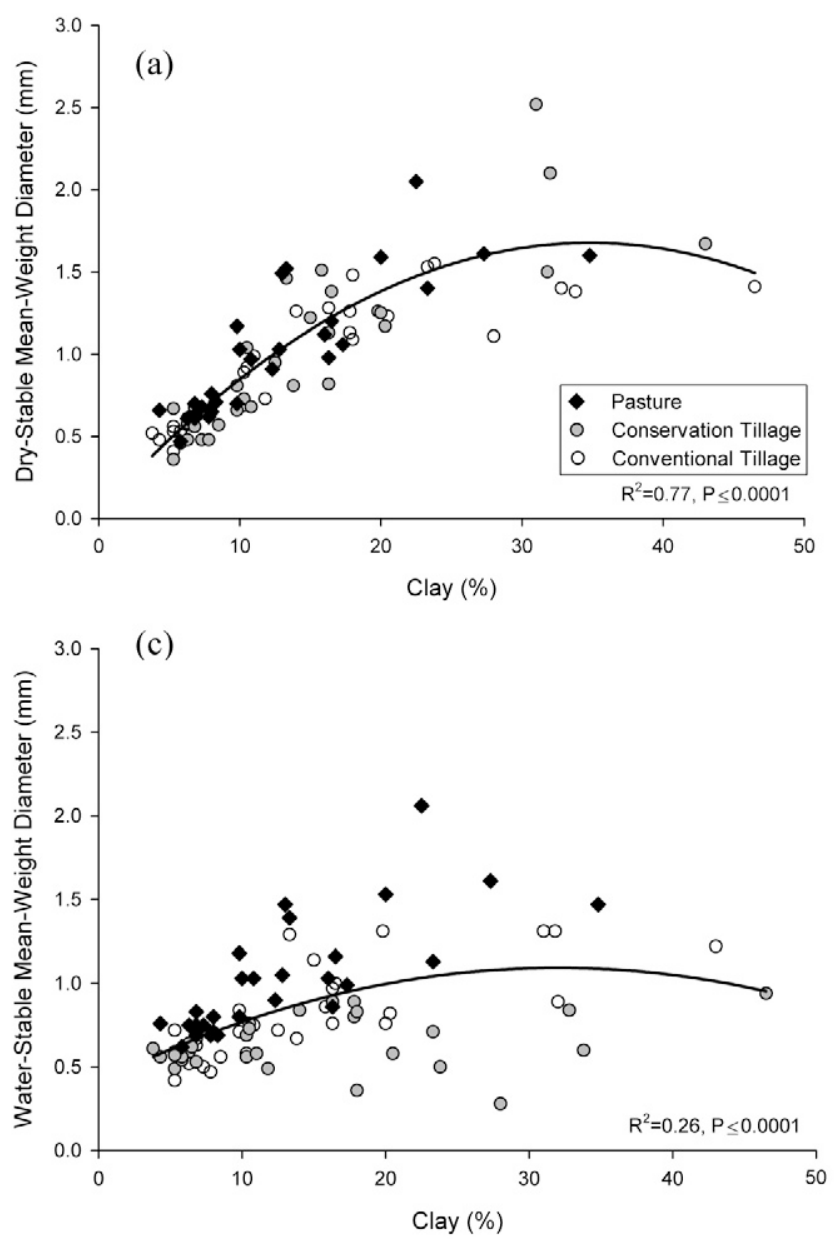

(b)

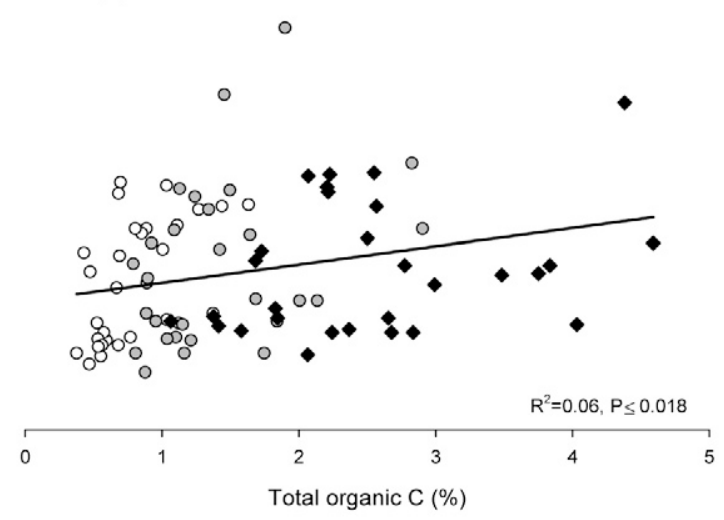

(d)

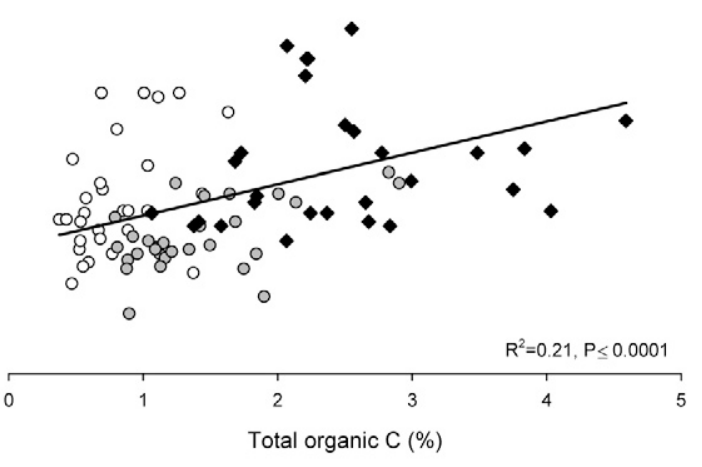

Fig. 7. Effect of surface-horizon clay and total soil organic $C$ concentration on (a and b) dry-stable and (c and d) water-stable mean-weight diameter of the 0- to 5-cm layer. Samples correspond to 87 sites in the Piedmont and Coastal Plain Major Land Resource Areas.

(2002) in south-central Texas, Alberta, and British Columbia. In northeastern Ohio, Jarecki et al. (2005) used the 0- to 5and 10 - to $20-\mathrm{cm}$ depths and reported stratification ratios $<2$ on a field with $14 \mathrm{yr}$ of no-till corn. They attributed this low value to the fact that corn root-derived $\mathrm{C}$ contributed more to SOC than stover-derived C. In southwestern Spain, SOC at 0

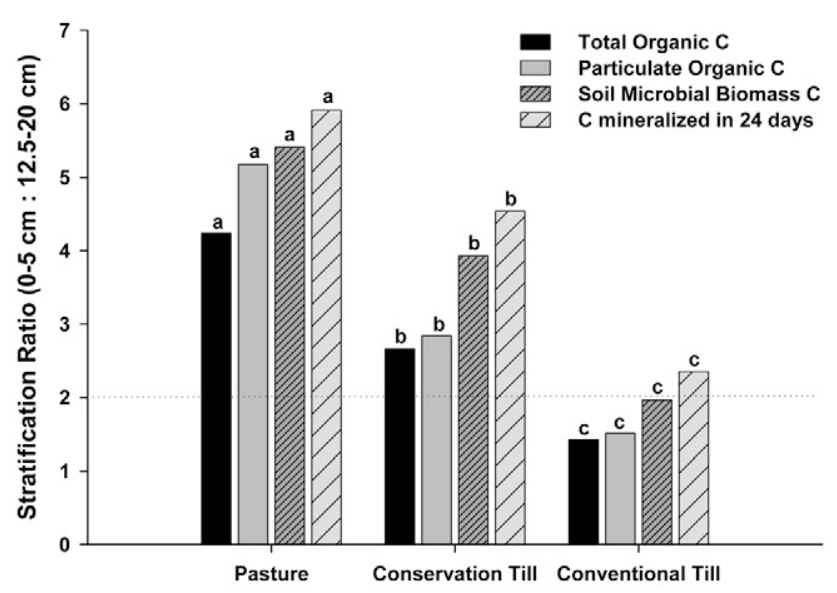

Fig. 8. Stratification ratio of soil organic $C$ fractions under pasture, conservation tillage, and conventional tillage. Bars sharing the same letter within a $C$ fraction are not different at $\boldsymbol{P}=\mathbf{0 . 0 5}$. Samples correspond to 87 sites in the Piedmont and Coastal Plain Major Land Resource Areas. to 5 and 5 to $10 \mathrm{~cm}$ divided by that at 10 to $25 \mathrm{~cm}$ resulted in stratification ratios between CsT and CvT that were not significantly different (Moreno et al., 2006). When the 25- to $40-\mathrm{cm}$ soil layer was used for the denominator, stratification ratios were $>2$ for Cs T and significantly greater than for CvT.

The stratification ratio of SOC was related to water-stable MWD (Fig. 9a). Although significant variation occurred $\left(R^{2}=\right.$ $0.20)$, the stratification ratio of SOC under CvT was $<2$ and the lowest water-stable MWD (<1.0) occurred under CvT. Higher values of water-stable MWD would be desirable, because it would indicate soil structural integrity during heavy rainfall events. There was also a significant response of the stratification ratio of SOC with years under CsT (Fig. 9b). The lowest values occurred during the first $5 \mathrm{yr}$ and the response reached a maximum about $10 \mathrm{yr}$ after switching from CvT to CsT. Even under long-term CsT (i.e., $30 \mathrm{yr})$, the surface layer $(0-5 \mathrm{~cm})$ was the zone of concentrated SOC. Although Loveland and Webb (2003) suggested that there was little quantitative evidence of a threshold for SOC, stratification ratios of SOC fractions may provide a conceptual framework for evaluating the importance of SOC on soil functions related to aggregation, water-use efficiency, and nutrient cycling.

\section{CONCLUSIONS}

This on-farm survey of SOC stocks and fractions in the southern Piedmont and Coastal Plain MLRAs complements 
controlled-experiment studies under cultivated systems and contributes much-needed data under pastures. Total SOC in the 0 - to 20-cm layer was greatest under pasture $\left(38.9 \mathrm{Mg} \mathrm{ha}^{-1}\right)$, intermediate under CsT $\left(27.9 \mathrm{Mg} \mathrm{ha}^{-1}\right)$, and lowest under CvT $\left(22.2 \mathrm{Mg} \mathrm{ha}^{-1}\right)(P<0.001)$.

All SOC fractions were strongly correlated $(r>0.84)$ across soils and management. The relationship between total SOC and POC indicated that SOC accumulation in this warm and humid region was largely attributed to an increase in the POC fraction; i.e., for every unit of total SOC accumulated, $42 \%$ consisted of POC. A cooler climate and higher surface horizon clay content resulted in higher SOC, but these had less influence than management.

Management affected SOC primarily at the soil surface $(0-5 \mathrm{~cm})$. Stratification ratios of SOC fractions were in the order: pasture $>\mathrm{CsT}>\mathrm{CvT}$. Results supported the proposed threshold for a stratification ratio of 2 to distinguish soils with improved soil quality from degraded soils. The stratification ratio as an indicator of soil quality needs further evaluation, however, especially regarding the depth of sampling and its relationship with other physical, biological, and chemical measurements of soil quality.

Policies that promote sod-based systems and conservation tillage will lead to significant SOC sequestration throughout the Piedmont and Coastal Plain, resulting in improved soil quality and the potential for mitigating $\mathrm{CO}_{2}$ emissions.

\section{ACKNOWLEDGMENTS}

We thank the USDA-ARS, National Soil Dynamics Laboratory and Auburn University for financial support of this research, and the Universidad Nacional de Asunción in Paraguay for supporting H.J. Causarano during his Ph.D. studies at Auburn University. The help provided by district soil conservationists of the NRCS and by the staff of the Virginia Cooperative Extension Service to locate sites for on-farm sampling in the states of Alabama, Georgia, South Carolina, North Carolina, and Virginia is greatly appreciated. Thanks are extended to Ms. Kimberly Freeland for her assistance during sample preparation, Ms. Peggy Mitchell and Mr. Steven Knapp for their support during laboratory analyses, and Dr. Juan Rodriguez for his guidance during sample preparation and for conducting $\mathrm{C}$ analyses on all samples.

\section{REFERENCES}

Balesdent, J., C. Chenu, and M. Balabane. 2000. Relationship of soil organic matter dynamics to physical protection and tillage. Soil Tillage Res. 53:215-230.

Beare, M.H., B.R. Pohland, D.H. Wright, and D.C. Coleman. 1993. Residue placement and fungicide effects on fungal communities in conventional and no-tillage soils. Soil Sci. Soc. Am. J. 57:392-399.

Blake, G.R., and K.H. Hartge. 1986. Bulk density. p. 363-382. In A. Klute (ed.) Methods of soil analysis. Part 1. Physical and mineralogical methods. 2nd ed. Agron. Monogr. 9. ASA and SSSA, Madison, WI.

Cambardella, C.A., and E.T. Elliott. 1992. Particulate soil organic matter changes across a grassland cultivation sequence. Soil Sci. Soc. Am. J. 56:777-783.

Christensen, B.T. 1996. Carbon in primary and secondary organomineral complexes. p. 97-165. In M.R. Carter and B.A. Stewart (ed.) Structure and organic matter storage in agricultural soils. Adv. Soil Sci. CRC Press, Boca Raton, FL.

Christensen, B.T. 2001. Physical fractionation of soil and structural and functional complexity in organic matter turnover. Eur. J. Soil Sci. 52:345-353.

Edwards, A.P., and J.M. Bremner. 1967. Microaggregates in soils. J. Soil Sci. 18:64-73.

Ellert, B.H., and J.R. Bettany. 1995. Calculation of organic matter and nutrients stored in soils under contrasting management regimes. Can. J.
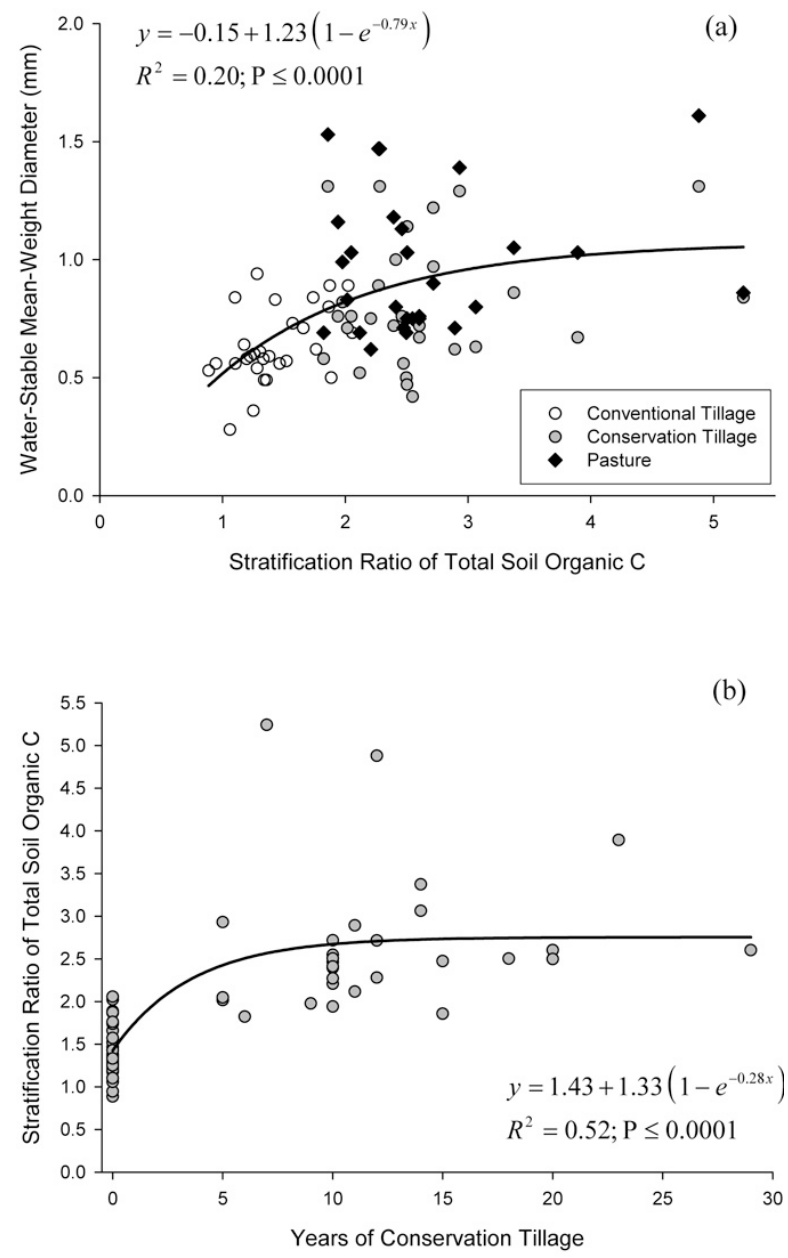

Fig. 9. Relationship of the stratification ratio of total organic $C$ to (a) water-stable mean-weight diameter and (b) number of years under conservation tillage. Samples correspond to 87 sites in the Piedmont and Coastal Plain Major Land Resource Areas.

Soil Sci. 75:529-538.

Elliott, E.T. 1986. Aggregate structure and carbon, nitrogen and phosphorus in native and cultivated soils. Soil Sci. Soc. Am. J. 50:627-633.

Fesha, I.G., J.N. Shaw, D.W. Reeves, C.W. Wood, Y. Feng, M.L. Norfleet, and E. van Santen. 2002. Land use effects on soil quality parameters for identical soil taxa. p. 233-238. In E. van Santen (ed.) Making conservation tillage conventional: Building a future on 25 years of research. Proc. Annu. Southern Conserv. Tillage Conf. Sustainable Agric., 25th, Auburn, AL. 24-26 June 2002. Alabama Agric. Exp. Stn. and Auburn Univ., Auburn, AL.

Franzluebbers, A.J. 1999. Potential C and $\mathrm{N}$ mineralization and microbial biomass from intact and increasingly disturbed soils of varying texture. Soil Biol. Biochem. 31:1083-1090.

Franzluebbers, A.J. 2002. Soil organic matter stratification ratio as an indicator of soil quality. Soil Tillage Res. 66:95-106.

Franzluebbers, A.J. 2005. Soil organic carbon sequestration and agricultural GHG emissions in the southeastern USA. Soil Tillage Res. 83:120-147.

Franzluebbers, A.J., and J.L. Steiner. 2002. Climatic influences on soil organic carbon storage with no tillage. p. 71-86. In J.M. Kimble et al. (ed.) Agricultural practices and policies for carbon sequestration in soil. Lewis Publ., Boca Raton, FL.

Franzluebbers, A.J., and J.A. Stuedemann. 2002. Particulate and nonparticulate fractions of soil organic carbon under pastures in the Southern Piedmont USA. Environ. Pollut. 116:S53-S62.

Franzluebbers, A.J., J.A. Stuedemann, H.H. Schomberg, and S.R. Wilkinson. 2000a. Soil organic C and N fractions under long-term pasture management in the Southern Piedmont USA. Soil Biol. Biochem. 32:469-478.

Franzluebbers, A.J., S.F. Wright, and J.A. Stuedemann. 2000b. Soil aggregation and glomalin under pastures in the Southern Piedmont USA. Soil Sci. 
Soc. Am. J. 64:1018-1026.

Gupta, V.V.S.R., and J.J. Germida. 1988. Distribution of microbial biomass and its activity in different soil aggregate size classes as affected by cultivation. Soil Biol. Biochem. 20:777-786.

Jarecki, M.K., R. Lal, and R. James. 2005. Crop management effects on soil carbon sequestration on selected farmers' fields in northeastern Ohio. Soil Tillage Res. 81:265-276.

Jenny, H. 1941. Factors of soil formation. McGraw-Hill, New York.

Johnson, J.M.F., D.C. Reicosky, R.R. Allmaras, T.J. Sauer, R.T. Venterea, and C.J. Dell. 2005. Greenhouse gas contributions and mitigation potential of agriculture in the central USA. Soil Tillage Res. 83:73-94.

Kelley, K.R. 1994. Conveyor-belt apparatus for fine grinding of soil and plant materials. Soil Sci. Soc. Am. J. 58:144-146.

Kemper, W.D., and R. Rosenau. 1984. Soil cohesion as affected by time and water content. Soil Sci. Soc. Am. J. 48:1001-1006.

Lal, R., J.M. Kimble, R.F. Follett, and C.V. Cole. 1998. The potential of U.S. cropland to sequester carbon and mitigate the greenhouse effect. Ann Arbor Press, Chelsea, MI.

Liebig, M.A., J.A. Morgan, J.D. Reeder, B.H. Ellert, H.T. Gollany, and G.E. Schuman. 2005. Greenhouse gas contributions and mitigation potential of agricultural practices in northwestern USA and western Canada. Soil Tillage Res. 83:25-52.

Loveland, P., and J. Webb. 2003. Is there a critical level of organic matter in the agricultural soils of temperate regions: A review. Soil Tillage Res. 70:1-18.

Martens, D.A., W. Emmerich, J.E.T. McLain, and T.N. Johnsen, Jr. 2005. Atmospheric carbon mitigation potential of agricultural management in the southwestern USA. Soil Tillage Res. 83:95-119.

Moreno, F., J.M. Murillo, F. Pelegrin, and I.F. Giron. 2006. Long-term impact of conservation tillage on stratification ratio of soil organic carbon and loss of total and active $\mathrm{CaCO}_{3}$. Soil Tillage Res. 85:86-93.

National Agricultural Statistics Service. 2002. Census of agriculture. Available at www.agcensus.usda.gov/Publications/2002/index.asp (verified 24 Oct. 2007). NASS, Washington, DC.

Nelson, S.D., and L.E. Sommers. 1982. Total carbon, organic carbon, and organic matter. p. 539-579. In A.L. Page et al. (ed.) Methods of soil analysis. Part 2. 2nd ed. Agron. Monogr. 9. ASA and SSSA, Madison, WI.

NRCS. 2006. Land Resource Regions and Major Land Resource Areas of the United States, the Caribbean, and the Pacific Basin. Agric. Handb. 296. Available at soils.usda.gov/survey/geography/mlra (verified 24 Oct.
2007). NRCS, Washington, DC.

Paustian, K., H.P. Collins, and E.A. Paul. 1997. Management controls on soil carbon. p. 15-49. In E.A. Paul et al. (ed.) Soil organic matter in temperate agroecosystems. CRC Press, Boca Raton, FL.

Reeves, D.W. 1997. The role of soil organic matter in maintaining soil quality in continuous cropping systems. Soil Tillage Res. 43:131-167.

Reeves, D.W., and D.P. Delaney. 2002. Conservation rotations for cotton production and carbon storage. p. 344-348. In E. van Santen (ed.) Making conservation tillage conventional: Building a future on 25 years of research. Proc. Annu. Southern Conserv. Tillage Conf. Sustainable Agric., 25th, Auburn AL. 24-26 June 2002. Alabama Agric. Exp. Stn. and Auburn Univ., Auburn, AL.

SAS Institute. 2003. The SAS system for Windows. Release 9.1. SAS Inst., Cary, NC.

Shaw, J.N., D.W. Reeves, and C.C. Truman. 2003. Clay mineralogy and dispersibility of soil and sediment derived from Rhodic Paleudults. Soil Sci. 168:209-217.

Shaw, J.N., C.C. Truman, and D.W. Reeves. 2002. Mineralogy of eroded sediments derived from highly weathered Ultisols of central Alabama. Soil Tillage Res. 68:59-69.

Skjemstad, J.O., L.J. Janik, and J.A. Taylor. 1998. Non-living soil organic matter: What do we know about it? Aust. J. Exp. Agric. 38:667-680.

Spatial Climate Analysis Service. 2005. PRISM Products Matrix. Available at prism.oregonstate.edu/products/matrix.phtml (verified 29 Oct. 2007). Oregon State Univ., Corvallis.

Tisdall, J.M., and J.M. Oades. 1982. Organic matter and water-stable aggregates in soils. J. Soil Sci. 33:141-163.

van Veen, J.A., J.N. Ladd, and M.J. Frissel. 1984. Modelling C and N turnover through the microbial biomass in soil. Plant Soil 76:257-274.

Voroney, R.P., and E.A. Paul. 1984. Determination of $k_{\mathrm{C}}$ and $k_{\mathrm{N}}$ in situ for calibration of the chloroform fumigation-incubation method. Soil Biol. Biochem. 16:9-14.

Wander, M. 2004. Soil organic matter fractions and their relevance to soil function. p. 67-102. In F. Magdoff and R.R. Weil (ed.) Soil organic matter in sustainable agriculture. CRC Press, Boca Raton, FL.

Wattel-Koekkoek, E.J.W., P.P.L. van Genuchten, P. Buurman, and B. van Lagen. 2001. Amount and composition of clay-associated soil organic matter in a range of kaolinitic and smectitic soils. Geoderma 99:27-49. 